\title{
The Contribution of Self-Adjustment and Learning Skill to Qur'an Memorization Achievement of Boarding School Students
}

\author{
Renti Gusti Mulia ${ }^{1}$, Neviyarni' ${ }^{2}$, Alizamar ${ }^{3}$ \\ ${ }^{123}$ Universitas Negeri Padang, Padang \\ ${ }^{*}$ Corresponding author, e-mail: renti_aila@yahoo.com
}

\begin{abstract}
Qur'an Memorization (Tahfiz Quran) score is a determinant factor of boarding students' graduation. However, Many of the students get the score below the standard (KKM). Their ability to get high achievement could be caused by several factors such as their self-adjustment toward the learning environment and their learning skill. This study was conducted to reveal students' self-adjustment, learning skill and achievement, and to perceive the contribution of aforementioned factors to students' achievement. It was using correlation research method where the data was analysed through description and double regression. The research sample was 220 students consisted of students of grade seven and eight in Junior High School ArRisalah Padang. The result showed that self-adjustment and learning skill were in high category while student's achievement was in moderate category. Then, there was a significantly positive contribution of the two factors on student's learning achievement. In other words, the higher student's self-adjustment and learning skill are the higher their learning achievement.
\end{abstract}

Keywords: Self-Adjustment, Learning Skills, Learning Achievement.

\section{Introduction}

Learning achievement is a determinant for students to continue their education. It will affect their educational stage. Prayitno dkk (2014) explained that student's learning achievement will be reasoning to determine student's educational 'fate' such as grade promotion, selection of majors, graduation, and even passing an university entrance exam like National Entrance Exam of State Tertiary Institution (SNMPTN). Level of student's achievement highly significantly affects student's graduation at school (Education et al., 2008). These two statements emphasizes the importance of high learning achievement in order students are able to compete on every educational stage.

Boarding school is unique and different from ordinary school. Students of boarding schools have tight schedule and many activities because they combine the national and 
boarding curriculums and include extracurricular activities (Zakiyah et al., 2010). They also have learning demands compared to ordinary schools because learning time in boarding schools is longer (Hastuti, 2016). One of the differences in learning system in boarding school, in this case Islamic boarding school, is the subject of Tahfizh Qur'an. This is the main program in every islamic boarding school for example in Junior High School (SMP) ArRisalah. This is a special subject and students are required to pass the standard score in order to graduate. Every student must memorize a number of surah every semester. If they don't meet the target, they cannot get their boarding school diploma.

The amount of learning demands and responsibility make students to have good selfadjustment to live in dorm for example, adapting to dorm rules, friends, teachers, and the dorm physical environment. The phenomenon of self-adjusting problems could be found in boarding schools. For example, 5-10 \% of freshmen in Islamic Modern Boarding School Assalam Surakarta were found to have low self-adjustment in following the school activity and adjusting to dorm lives because they could not separate from parents, break the school rules etc. (Pritaningrum \& Hendriani, 2013). The high pressure of school demands affects student's psychology and behaviour (Netrawati et al., 2018). What we found in SMP ArRisalah Padang was problems such as students ingonored their duties, came late to Masjid, felt bored, often called their parents, and even moved to other school because they could not stand the demands in dorm.

Tight schedule at school and dorm require students to have skills in learning especially when it comes to memorizing Qur'an (Tahfizh Qur'an). If they have a good learning skill, they will easily feel bored and lazy and it will affect their achievement poorly. Learning skills are skills students must have in order to success in learning (Nirwana, Zuwirna, Hasanuddin, Yuskal, \& Neviyarni, 2006). Learning skills have important role in improving student's achievement (Syafni et al., 2013). It is one of the prerequirements in order to success in learning (Nasution, 2001). It also gives positive constribution in student's learning achievement (Pasternak, 2013). The learning skill problems that should be improved in SMP Ar-Risalah Padang were students came late to Tahfizh program after Subuh; students did not wear uniforms because they were gone or dirty, they said; students were sleeping during the program; students stay late to memorize the Qur'an; Many students did not come to school when they had a test in their classes; and 159 students were not able to meet the target of Tahfizh Qur'an Program.

Some of these phenomena showed problems in self-adjustment and learning skill. They needed special attention because they could lead to other problems like learning achievement, in this case in Tahfizh Qur'an subject in boarding schools. Therefore, it is one Guidance and Counseling role in improving boarding student's self-adjustment and learning skills for Tahfizh Qur'an subject in SMP Ar-risalah Padang. The Counselor should arrange the program based on need assessment and provide counseling service according to student problem at school and in dormitory. We gained information that Guidance and Counseling services were not done maximally and met the school expectation. Guidance and Counseling program special to boarding student problems and their learning achievement problems were not available. The counselor teacher only provided general counseling session. However, the services were still not fully based on the designed program.

Guidance and Counseling services have a purpose to help students live their school lives well. Prayitno, Wibowo, Marjohan, Mugiarso, \& Ifdil (2014) stated that guidance and counseling session or services are services done by professionals to a person or a group for 
the sake of improving their disturbed effective daily lives, improving self-focus to be independent and self-control so that they can improve their learning process. By participating in Guidance and Counseling session, students can avoid their disturbed effective daily lives (KES-T), improve their effective daily lives (KES) and become independent. Counselor teacher should cooperate with school and dorm teachers for students to develop and learn effectively so that they can achieve maximum result both at school and dorm. The phenomena and the importance of Guidance and Counseling role mentioned above became the reason why this study should be conducted in order to find ways to solve the problems related to student self-adjustment and learning skills in SMP ArRisalah Padang.

\section{Method}

This study was a descriptive quantitative research using correlational approach. It was analysed through description and double regression using Statistical Product and service Solution (SPSS) program version 20.00. The research population were students of grade seven and eight with the total of 489 students. The population was conssited of 16 classe. To select the sample, we used Proportional Random Sampling technique, and choose 220 students. The research instruments were self-adjustment and learning skill questionaires. To ensure the instrument reliability, we used Rasch Model and got an alpha cronbach value of self-adjustment questionnaire 0,80 and learning skill questionnaire 0,84 . In other words, the interaction between person and questionnaire items was generally good for the first questionnaire and very good for the later one.

\section{Results and Discussion}

Generally, student self-adjustment in SMP AR-Risalah Padang is high. Of the 220 students, 121 students (55\%) have high self-adjustment. Only 0,45\% of the students have love self-adjustment. The highest average score of self-adjustment indicator is 'environment' with a percentage of $80,07 \%$ (high). The indicator of 'friends of same age' is $80,07 \%$ (high), 'rules' is $78,88 \%$ and dorm teacher is $78,10 \%$. The details of dtudent self-adjustment analysis can be seen in the following tables.

Table 1. Description of Self-Adjustment Frequency based on categories $(n=220)$.

\begin{tabular}{|c|c|c|c|}
\hline $\begin{array}{c}\text { Interval } \\
\text { Score } \\
\end{array}$ & Categories & Frequency $(F)$ & $\begin{array}{c}\text { Percentage } \\
(\%)\end{array}$ \\
\hline$\geq 161$ & Very High (ST) & 76 & 34.54 \\
\hline $131-160$ & High (T) & 121 & 55 \\
\hline $101-130$ & Quite High (CT) & 22 & 10 \\
\hline 70- 100 & Rendah (R) & 1 & 0.45 \\
\hline$\leq 69$ & $\begin{array}{c}\text { Sangat Rendah } \\
\text { (SR) }\end{array}$ & 0 & 0 \\
\hline \multicolumn{2}{|c|}{ Total } & 220 & 100 \\
\hline
\end{tabular}




\section{Learning Skills}

The data showed that student learning skills in SMA Ar-Risalah is generally in high category. 98 students ( $44,55 \%$ ) have high learning skills. Only $2.27 \%$ of the students have low leaning skills. The highest indicator is 'taking exam' (77,53\%). Following 'learning process' skill is $71,95 \%$. The indicator of memorizing skill is $69.78 \%$, student concentration and tenacity in learning Tahfizh Qur'an is $69,78 \%$. The lowest average score is in time management skill with a percentage of $62.92 \%$. the details is presented in the following table.

Table 3. Distribution of Learning Skill Frequency based on category $(n=220)$

\begin{tabular}{|c|c|c|c|}
\hline Interval Score & Categories & Frequency (F) & Percentage (\%) \\
\hline $\mathbf{2 1 2 3}$ & Very High (ST) & 23 & 10.45 \\
\hline $\mathbf{1 0 0 - \mathbf { 1 2 2 }}$ & High (T) & 98 & 44.55 \\
\hline $\mathbf{7 7 - \mathbf { 9 9 }}$ & Quite High (CT) & 94 & 42.73 \\
\hline $\mathbf{5 4 - 7 6}$ & Low (R) & 5 & 2.27 \\
\hline$\leq \mathbf{5 3}$ & Very Low (SR) & 0 & 0 \\
\hline \multicolumn{2}{|c|}{ Total } & 220 & 100 \\
\hline
\end{tabular}

Table 4. Description of Percentage Average of Learning Skill based on Indicators

\begin{tabular}{|c|c|c|c|c|c|c|c|c|c|}
\hline Variable & Indicator & \multicolumn{7}{|c|}{ Score } & De \\
\cline { 3 - 11 } & & $\begin{array}{c}\text { Ide } \\
\mathrm{al}\end{array}$ & Highest & $\begin{array}{c}\text { Lowes } \\
\mathrm{t}\end{array}$ & Total & $\begin{array}{c}\text { Ave- } \\
\text { rage }\end{array}$ & $\%$ & SD & s \\
\hline \multirow{2}{*}{$\begin{array}{c}\text { Learning } \\
\text { Skill in } \\
\text { Tahfizh } \\
\text { Quran }\end{array}$} & $\begin{array}{c}\text { Learning } \\
\text { Process }\end{array}$ & 30 & 30 & 13 & 4749 & 21.59 & 71.95 & 3.48 & $\mathrm{~T}$ \\
\cline { 2 - 12 } & Memorizing & 40 & 40 & 16 & 6141 & 27.91 & 69.78 & 4.54 & $\mathrm{~T}$ \\
\cline { 2 - 11 } & Taking Exam & 40 & 40 & 18 & 6823 & 31.01 & 77.53 & 4.40 & $\mathrm{~T}$ \\
\cline { 2 - 11 } & $\begin{array}{c}\text { Time } \\
\text { Management }\end{array}$ & 35 & 35 & 9 & 4845 & 22.02 & 62.92 & 4.89 & $\mathrm{CT}$ \\
\hline \multicolumn{2}{|c|}{ Total } & 145 & 145 & 68 & 22558 & 102.54 & 70.71 & 13.83 & $\mathrm{~T}$ \\
\hline
\end{tabular}

\section{Learning Achievement}

Most of students have moderate learning achivement with the total of 102 tudents $(46,4 \%)$ out of 220 students. 50 students are in the low with a percentage of $22,7 \%$. There are 30 students in the high category (13,6\%). 23 students are in very low category (10,5\%), and 15 students are in very high category $(6,8 \%)$.

Table 5. Distribution of Learning Achievement Frequency in Tahfizh Qur'an (n=220)

\begin{tabular}{|c|c|c|c|}
\hline Interval Score & Categories & $\begin{array}{c}\text { Frequency } \\
(\mathbf{F})\end{array}$ & Percentage (\%) \\
\hline $\mathbf{9 5 - 1 0 0}$ & Very High (ST) & 15 & 6,8 \\
\hline $\mathbf{9 0 - 9 4}$ & High (T) & 30 & 13,6 \\
\hline $\mathbf{8 4 - 8 9}$ & Moderate (S) & 102 & 46,4 \\
\hline $\mathbf{7 8 - 8 3}$ & Low (R) & 50 & 22,7 \\
\hline$\leq 77$ & Very Low (SR) & 23 & 10,5 \\
\hline \multicolumn{2}{|c|}{ Total } & 220 & 100 \\
\hline
\end{tabular}




\section{Normality Test}

The result of normality test shows that the data has normal distribution. The numbers could be seen in the following table.

Table 6. Result of Normality Test.

\begin{tabular}{|c|c|c|c|c|}
\hline No & Variable & Sig. $(p)$ & $\begin{array}{c}\text { Sig. } \\
\text { alpha }\end{array}$ & Description \\
\hline 1 & Self-Adjustment $\left(\mathrm{X}_{1}\right)$ & 0,38 & & Normal \\
\hline 2 & Learning Skill $\left(\mathrm{X}_{2}\right)$ & 0,132 & 0,05 & Normal \\
\hline 3 & Learning Achievement $(\mathrm{Y})$ & 0,072 & & Normal \\
\hline
\end{tabular}

\section{Linearity Test}

The result shows that $X_{1}$ and $X_{2}$ are linear to $Y$. The following table describes the result from linearity test.

Table 7. Analysis of Linearity Test of $X_{1}$ dan $X_{2}$ toward $Y$

\begin{tabular}{|c|c|c|c|c|}
\hline No & Variable & $\mathrm{F}$ & $\begin{array}{c}\text { Deviation from } \\
\text { Linearity }\end{array}$ & Description \\
\hline 1 & $\mathrm{X}_{1}$ Y Self-Adjustment & 30,612 & 1,018 & Linier \\
\hline 2 & $\mathrm{X}_{2}$ Y Learning Skill & 19,318 & 1,200 & Linier \\
\hline
\end{tabular}

\section{Multicollinearity Test}

The result obtained from multicollinearity test shows that there is not any multicollinerity between variable $X_{1}$ and $X_{2}$. The result can be checked in the following table.

Table 8. Result of Multicollinearity Test of Self-Adjustment Variable and Learnig Skill

\begin{tabular}{|c|c|c|}
\hline Variable(Constant) & Tolerance & VIF \\
\hline $\mathrm{X}_{1}$ & 1,000 & 1,000 \\
\hline $\mathrm{X}_{2}$ & 1,000 & 1,000 \\
\hline
\end{tabular}

The Testing of Self-Adjustment and Learning Skill toward Student Learning Achievement

Table 9. Result of Simultaneous Regression Analysis on Self-Adjustment $\left(X_{1}\right)$ and Learning Skill $\left(\mathrm{X}_{2}\right)$ and Learning Achievement $(\mathrm{Y})$

\begin{tabular}{|c|c|c|}
\hline Variabel & $\mathrm{R}$ & $\mathrm{R}$ Square \\
\hline $\mathrm{X}_{1} \mathrm{X}_{2}-\mathrm{Y}$ & 0,361 & 0,131 \\
\hline
\end{tabular}

According table 9, the coefficient correlation of self-adjustment and learning skills to learning achievement is 0,361. Simultaneously, the contribution of self-adjustment and learning skill to learning achievement is $13,1 \%$ which means self-adjustment and learning 
skill can predict studen learning achievement. That being said, self-adjustment and learning skill positively and significantly contribute student learning achievement.

\section{Discussion}

\section{Student Self-Adjustment}

Student self-adjustment is student's effort to live, do activities, get along with others in dormitory environment by adjusting their needs with applicable values and norms so that they can live in harmony with their environment. The result of this research revealed that self-adjustment of SMP Ar-Risalah Padang students was generally high especially towards the dorm environment and condition, dorm rules, dorm teachers, and friends of same age.

Another research also found that students were able to adjust their self to school rules, teachers. And friends of same age (Sagita et al., 2013). Factors affecting student selfadjustment are such as physical condition, personality, will to change, training, school environment, family and society (Pritaningrum \& Hendriani, 2013). Boarding school rules are made for students so that they can implement life principles because the students in a boarding school are demanded to live independently. The tight schedule in the dormitory will be done easily and orderly by following rules. Harmonious relationship between friends of same age will create comfort for them to get along naturally. Student effort to foster good relationship with their dorm teachers will improve their motivation in learning.

When students can adjust with the dorm environment, they can live their lives comfortably without any pressure. A good self-adjustment is when someone can avoid stress and feel comfort Schneider (Hasan \& Handayan, 2014). Student self-adjustment in ArRisalah that needs improvement is the relationship between students and dorm teachers. One way that can be done is thorugh the implementation of counseling session special for students with dorm related problems. The service could be like providing information and understanding the content related to student self-adjustment in the dormitory in SMP ArRisalah Padang.

\section{Student Learning Skill}

Learning skills are techniques of effective learning mastered by students in preparing, participating in learning process and following up the activities after learning in order to get maximum achievement. This study found that in general learning skill of Ar-Risalah students was high especially in terms of taking the test of Tahfizh Qur'an. This also means that students skill in following the test should be maintained. Meanwhile the poor indicator, student's 'time management' should be improved.

Generally, Learning skill affects students success in learning. As stated by Nasuition in his research that student success in learning could be affected by student learning skills (Nasution, 2001). In addition, Syafni et.al. mentioned student's 6 major learning problems. They are skills in managing time, reading book, memorization, following learning process in the classroom, summarizing textbook, concentration, remembering, and tenacity in learning (Syafni et al., 2013). Many students complained the lack of time for them to study, however the real problem is their ability in time management.

The problem in memorizing skill will happen when student cannot understand the materials in details (Prayitno et al., 2001). Based on that notion, students in this research were not able to understand the contents of surahs or verses to be memorized. Problems in 
remembering, concentration and tenacity in laerning are caused by internal factor such as tired physical condition (Syafni et al., 2013). Due to the tigh schedule of boarding school, student are expected to maintain a balanced diet, and a good quality rest. Moreover, problems in student learning process also could be affected by student skill in learning for example mastering effective memorizing method. In general, the problems related to student learning skill are due to student ignorance in deciding the nest method for them to go through learning process (Tanjung, 2018). This research found that student skill in time management is in quite high category or moderate. Therefore, this skill should be improved.

\section{Student Learning Achievement}

In general, student learning achievement in SMP Ar-Risalah Padang is in moderate category, $102(46,4 \%)$ out of 220 students. This indicates that student achievement in Tahfizh Qur'an need improvement. Because learning achievement is one of the important determinants for students to continue their next educational stage. Prayitno, Wibowo, Marjohan, Mugiarso, \& Ifdil (2014) explain that student achievement will be consideration for deciding their educational 'fate' such as grade promotion, major selection, graduation, and passing the national entrance exam for state tertiary institutions (SNMPTN).

Considering the importance of learning achievement, self-adjustment and learning skill towards Tahfizh Quran learning process, there needs an improvement by doing tutoring and imprementing Guidance and Counseling services maximally in the dorm. One of the ways is by implementing counseling service program according to student needs that are related to factors that could affect student learning achievement in the dormitory. The service could be in forms of individual counseling session, information service, mastering content service, and placement and distribution service. According to Yusnimar's research (Marimbuni et al., 2017) the services could be given by the counselor to help student selfadjustment are like orientation service, providing information, personal counseling, placement and distribution, and group counseling service. Counselor can give information service, mastering content servicem and group counseling service related to learning skill. Subject teachers should also actively ensure and observe the students with low learning skills to use various methods in learning (Folastri, 2013).

\section{The Conribution of Sel-Adjustment and Learning Skill to Tahfizh Qur'an Achievement}

Simultaneously, there is a positive and significant contribution between self-adjustment and learning skill to student learning achievement. In other words, the level of student selfadjustment and learning skill will affect the level of student learning achievement positively. The higher student self-adjustment and learning skill are the higher student achievement is and vice versa. This finding is accordance to the research by Suryadi (2015), stating that selfadjustment can improve student learning achievement Tallent (Suryadi,2015). There was a positive and significant correlation between self-adjustment and student math achievement. If self-adjustment is good, learning achievement is also good (Suryadi, 2015). Another research also revealed that there is a correlation between student way of learning and their learning achievement. In their research, Ernita et al. Found that the students of civic class had a very good learning achievement because they most of them implemented an effective learning method by arranging their learning schedule at home (Ernita et al., 2016). Every student has different way of learning in Tahfizh Qur'an. Some of them are leaning through 
listening, some are writing, and others are making mind mapping, and many other ways could be used by students. In this case, the way of learning could be also caled as learning style. There are four learning style found by Kolb ; (1) Accomodator, a learning style that prefers experience and active experiment by direct practice, (2)Diverger, a learning style by seeing (visual) and listening (audio), (3) Converger, a student who learns by thinking and doing, and (4) Assimilatory, a learning style by thinking, seeing and listening Kolb (Orang et al., 2009). According to hypothesis analysis in this research, it can be concluded that selfadjustment and learning skill positively contribute to student learning achevement in Tahfizh Quran. hadap In other words, the two variables give contribution to learning achievement in Tahfizh Qur' an progam in SMP Ar-Risalah Padang.

\section{Conclusion}

From the discussion, a conclusion can be drawn as folow: student self-adjustment in the dormitory of SMP Ar-Risalah is generally good, and so is student learning skill. However, student skill in time management should be improved in the future. So is the student learning achievement. The result also said that if student self-adjustment and learning skill are higher, student learning achievement will be higher.

\section{References}

Education, W. B., Questionnaire, D. I., \& Based, W. (2008). Factors That Influence Academic Achievement. 1(1).

Ernita, T., \& Fatimah, R. A. (2016). Hubungan cara belajar dengan prestasi belajar siswa dalam mata pelajaran PKN pada siswa kelas X SMA Negeri 1 Banjarmasin. Jurnal Pendidikan Kewarganegaraan, 6(11).

Folastri, S. (2013). Perbedaan keterampilan belajar siswa berprestasi tinggi dan berprestasi rendah serta implikasinya dalam bimbingan dan konseling. Konselor, 2(1).

Hastuti, F. (2016). Pengaruh disiplin belajar terhadap kesulitan belajar ekonomi siswa kelas $\mathrm{x}$ sekolah berasrama di kota padang panjang. Journal Educative: Journal of Educational Studies, 1(2), 168-177.

Marimbuni, M., Syahniar, S., \& Ahmad, R. (2017). Kontribusi Konsep Diri Dan Kematangan Emosi Terhadap Penyesuaian Diri Siswa Dan Implikasinya Dalam Bimbingan Dan Konseling. Insight Jurnal Bimbingan Konseling, 6(2), 165-175.

https://doi.org/10.21009/insight.062.05

Nasution, H. F. (2001). Hubungan metode mengajar dosen, keterampilan belajar, sarana belajar dan lingkungan belajar dengan prestasi belajar mahasiswa. Jurnal Ilmu Pendidikan, 8(1).

Netrawati, N., Khairani, K., \& Karneli, Y. (2018). Upaya Guru BK untuk Mengentaskan Masalah-Masalah Perkembangan Remaja dengan Pendekatan Konseling Analisis Transaksional. Islamic Counseling: Jurnal Bimbingan Konseling Islam, 2(1), 79. https://doi.org/10.29240/jbk.v2i1.463

Orang, N., Dwi, S., \& Pujiningsih, P. S. (2009). Sawitri Dwi Prastiti dan Sri Pujiningsih Pengaruh Faktor Preferensi Gaya Belajar terhadap Prestasi Belajar Mahasiswa Akuntansi. 3, 224-231. http://fe.um.ac.id/wp-content/uploads/2010/01/sawitri_pujiningsih 6.pdf

Pasternak, R. (2013). Discipline ,Learning Skills and Academic Achievement. Journal of Arts 
and Education, 1(June), 1-11.

Prayitno, Wibowo, M. E., Marjohan, Mugiarso, H., \& Ifdil. (2014). Pembelajaran melalui pelayanan bimbingan dan konseling di satuan pendidikan. Padang: UNP Press.

Pritaningrum, M., \& Hendriani, W. (2013). Penyesuaian Diri Remaja Yang Tinggal Di Pondok Pesantren Modern Nurul Izzah Gresik Pada Tahun Pertama. Jurnal Psikologi Kepribadian Dan Sosial, 02(03), 141-150. https://doi.org/10.1017/CBO9781107415324.004

Sagita, D. D., Erlamsyah, E., \& Syahniar, S. (2013). Hubungan Antara Perlakuan Orangtua Dengan Penyesuaian Diri Siswa Di Sekolah. Konselor, 2(1). https://doi.org/10.24036/02013211248-0-00

Syafni, E., Syukur, Y., \& Ibrahim, I. (2013). Masalah Belajar Siswa dan Penanganannya. Konselor, 2(2), 15-19. https://doi.org/10.24036/02013221721-0-00

Schneiders, A.A. 1964. Personal Adjustment and Mental Health. New York: Rinehart and Winston.

Setiono, V., dan Pramadi, A. 2005. Pelatihan Asertivitas dan Peningkatan Perilaku Asertif Pada Siswa-Siswi SMP. Anima: Indonesian Psychological Journal. Vol. 20, No. 2, 149168.

Sunarto, H., dan Hartono, B.A. 2006. Perkembangan Peserta Didik. Jakarta: Rineka Cipta. Suriyadi. 2015. Hubungan penyesuaian diri dan motivasi belajar dengan prestasi belajar. Tesis. Padang: UNP.

Tanjung, R. F. (2018). Increasing skills reading students through guidance and counseling classical using Contextual Teaching and Learning ( CTL ) approach. 03(01), 8-14. https://doi.org/10.24036/0037za0002

Widayati, C.S. 2002. Reformasi Pendidikan Dasar . Jakarta : Grasindo.

Yong, F.S. 2010. A Study on The Assertiveness and Academic Procrastination of English and Communication Student at a Private University. American Journal of Scientific Research. Issue. 9, 62-72.

Zakiyah, N., Hidayati, F.N.R., dan Setyawan, I. 2010. Hubungan Antara Penyesuaian Diri dengan Prokrastinasi Akademik Siswa Sekolah Berasrama SMP N 3 Peterongan Jombang. Jurnal Psikologi Undip. Vol. 8, No. 2, 156-167. 